\title{
New record of an alien plant, Desmodium paniculatum (Fabaceae), in Korea based on a morphological examination and DNA barcoding
}

\author{
Dong-Pil JIN, Jung-Hyun KIM, Sunhee SIM, Hwa-Jung SUH ${ }^{1}$ and Jin-Seok KIM* \\ Plant Resources Division, National Institute of Biological Resources, Incheon 22689, Korea \\ ${ }^{1}$ Department of Biology, Daejeon University, Daejeon 34520, Korea \\ ${ }^{2}$ Current address: Geumsugangsan, Uijeongbu 11625, Korea \\ (Received 19 March 2021; Revised 8 May 2021; Accepted 10 June 2021)
}

\begin{abstract}
Desmodium paniculatum (Fabaceae), native to North America and an alien plant in Japan, was newly found in Hwaseong-si and Daejeon-si, Korea. This species is distinguished from Korean-related taxa based on certain morphological features. Specifically, it is a perennial herb, with a 4-5 jointed loment, and with the basal suture moderately incised between the articles. In the field, D. paniculatum grows around rivers and roadsides, suggesting that it is likely to have been introduced through river improvement work and road construction. On the phylogenetic tree based on an internal transcribed spacer, Korean individuals forms a clade with a Japanese individual. Here, we report a morphological description, photographs, an illustration, and the locality of $D$. paniculatum.
\end{abstract}

Keywords: Alien plant, Desmodium paniculatum, Fabaceae, new record, plant resource

Genus Desmodium Desv. (family Fabaceae, tribe Desmodieae) consists of ca. 275 species, and this genus is widely distributed from tropical to temperate forests around the world. Southeast Asia, Mexico, and South America are considered as the centers of species diversity in this case (Ohashi, 2005). Members of Desmodieae, including Desmodium, have been used in traditional medicine and for foraging materials (Jabbour et al., 2018; Li et al., 2019). This genus was traditionally distinguished from related genera by its morphological features, such as its 3foliolate leaves, non-winged petiole, and distinctly jointed and usually indehiscent fruits (Ohashi et al., 1981). However, molecular phylogenies have constantly indicated polyphyly of Desmodium (Kajita et al., 1996; Jabbour et al., 2018; Ohashi et al., 2018). Given these findings, Desmodium has been classified into satellite genera, specifically Grona Lour. (Ohashi and Ohashi, 2018), Hylodesmum H. Ohashi \& R. R. Mill (Ohashi and Mill, 2000), and Ohwia H. Ohashi (Ohashi, 1999). In Korea, seven taxa of Desmodium are recognized (Choi, 2007), whereas six taxa apart from $D$. heterocarpon have recently been considered as members of Hylodesmum or Ohwia (Lee et al., 2012). In addition to these seven Korean taxa, $H$. laxum (Candolle) H. Ohashi \& R. R. Mill subsp. laxum was additionally recorded from forest lands of Jeju Island (Lee et al., 2012). In the case of $D$. heterocarpon, the taxonomic position was changed to the genus Grona, a resurrected name, according to molecular phylogeny studies (Ohashi and Ohashi, 2018).

Desmodium paniculatum (L.) DC. is a perennial herb that is widely distributed in North America (GBIF Secretariat, 2019). This species is known to be difficult to distinguish from related taxa, such as D. perplexum B. G. Schub. and D. glabellum (Michx.) DC., due to considerable morphological variation (Isely, 1983). Moreover, many hybrids related to D. paniculatum have been suggested (Isely, 1998). In this regard, Ohashi (2013) decided to regard species with wide concepts as a group until more evidence is found. There is difficulty in circumscribing the boundary of $D$. paniculatum, but this species has been reported in various provinces of Japan as a naturalized plant (Shimizu, 2003; Mito and Uesugi, 2004). Recently, this species was found in Korea, and this has never been reported. In the present study, we report the morphological characteristics and distribution of D. paniculatum in Korea. Also, we provide a

\footnotetext{
*Author for correspondence: webdogam@naver.com
} 
key to identify it considering related species. This species is differentiated from related taxa through a phylogenetic analysis.

\section{Material and Methods}

\section{Morphological analysis}

The morphological observations of $D$. paniculatum were conducted on living plants in the field and dried specimens in the herbarium of the National Institute of Biological Resources in Korea (KB). In addition, we examined additional specimens deposited in the herbarium of Inha University (IUI). A Nikon D750 (Nikon, Tokyo, Japan) camera was used to take photographs in the field survey. The measurements of the morphological characters were performed with a digital Vernier caliper and with data derived from field notes.

\section{DNA extraction and PCR}

Total genomic DNA samples were extracted from the leaves of two dried specimen (Voucher Nos. KIMJH20121 and KIMJH20122) with a MG Plant Genomic DNA Extraction SV Miniprep kit (MGmed, Seoul, Korea) according to the manufacturer's instruction. We used PCR amplification for the internal transcribed spacer (ITS) of nuclear ribosomal DNA, and we chose primers designed in previous studies (White et al., 1990; Jin et al., 2019). We conducted PCR with a GeneAmp PCR System 2700 Thermal Cycler (Applied Biosystems, Foster City, CA, USA). The PCR reaction mixture included the MG $2 \times$ Taq MasterMix with a dye (MGmed), $10 \mathrm{ng}$ of DNA, $0.3 \mu \mathrm{M}$ primers, and distilled water. Conditions included initial denaturation at $94^{\circ} \mathrm{C}$ for $3 \mathrm{~min}$ followed by 30 cycles each at $94^{\circ} \mathrm{C}$ for $30 \mathrm{~s}, 53^{\circ} \mathrm{C}$ for $45 \mathrm{~s}$, and $72^{\circ} \mathrm{C}$ for $1 \mathrm{~min}$. The total volume was $50 \mu \mathrm{L}$. The PCR products were visualized on $2 \%$ agarose gels, which were then processed with a MG PCR purification kit (MGmed). Sequencing was conducted with MACROGEN (Macrogen Inc., Seoul, Korea), and two sequences of Korean D. paniculatum were identical. The sequence identified in this study was deposited into the GenBank database (MW740337).

\section{Phylogenetic analysis}

To identify Korean D. paniculatum, a neighbor-joining (NJ) tree of tribe Desmodieae was constructed. In total, 33 taxa within the tribe were included considering earlier work on the DNA barcoding of Korean Desmodieae (Jin et al., 2019) and North American Desmodium species. Specifically, multiple sequences per taxon were accessed for $D$. paniculatum and taxa belonging to the same subtribe Desmodiinae. Two species [Acacia ligulata Aiton ex Steud. and Glycine max (L.) Merr.] were added as outgroups. All sequences were aligned with MAFFT (Katoh and Standley, 2013). To assess the confidence of the phylogenetic relationships, a bootstrap test was conducted with 1,000 resamplings for the $\mathrm{NJ}$ analysis. Kimura's two-parameter model (Kimura, 1980) was selected as the substitution model.

\section{Results and Discussion}

In the present study, we observed D. paniculatum in the field (Hwaseong-si and Daejeon-si), after which we determined this species as an alien plant in Korea. These habitats are located around rivers and roadsides, and we considered that $D$. paniculatum was therefore introduced into Korea through river improvement work and/or road construction. In terms of morphology, this species harbors a non-winged petiole, a subsessile and 4-5 jointed loment, and a moderately incised basal suture of the fruit (Figs. 1,2), which are distinguished from related genera Ohwia and Hylodesmum (Choi, 2007). Within Korean Desmodium, the erect and ascending stem of D. paniculatum is distinguishable from the procumbent and ascending stem of $D$. heterocarpon (Lee, 1980). Regarding the terminal leaflets, the lanceolate to ovate shape of $D$. paniculatum is different from the obovate or elliptic leaflets of D. heterocarpon (Figs. 1, 2) (Lee, 1980).

On the NJ tree based on ITS (Fig. 3), Desmodium taxa were constructed as monophyletic, and Korean $D$. paniculatum was classified as a clade independent from other members of Korean Desmodieae. It appears to be possible to identify $D$. paniculatum from other Desmodieae in Korea. However, it is difficult to identify $D$. paniculatum from other North American taxa. This may be related to the complex morphological variation within $D$. paniculatum due to recent speciation or putative hybridization (Isely, 1983, 1998; Ohashi, 2013). Short sequences of ITS (total aligned $374 \mathrm{bp}$ ) also may only provide insufficient information with regard to distinguishing the relationships among $D$. paniculatum and other species. The analysis of a combined DNA barcode regions (ITS $+r b c \mathrm{~L}+$ $m a t \mathrm{~K}$ ) for Korean Desmodieae showed a higher resolution than that of only one DNA barcode (Jin et al., 2019). Unfortunately, employing a combined sequence in this study was limited due to the absence of an available sequence acquired from one individual. Instead, we found that Korean D. paniculatum (MW740337) formed a clade with Japanese D. paniculatum (LC600886) (bootstrap value $=66 \%$ ); accordingly, we suggest the hypothesis that Korean individuals were introduced from Japan or from the same locality at which Japanese individuals were originally introduced. 

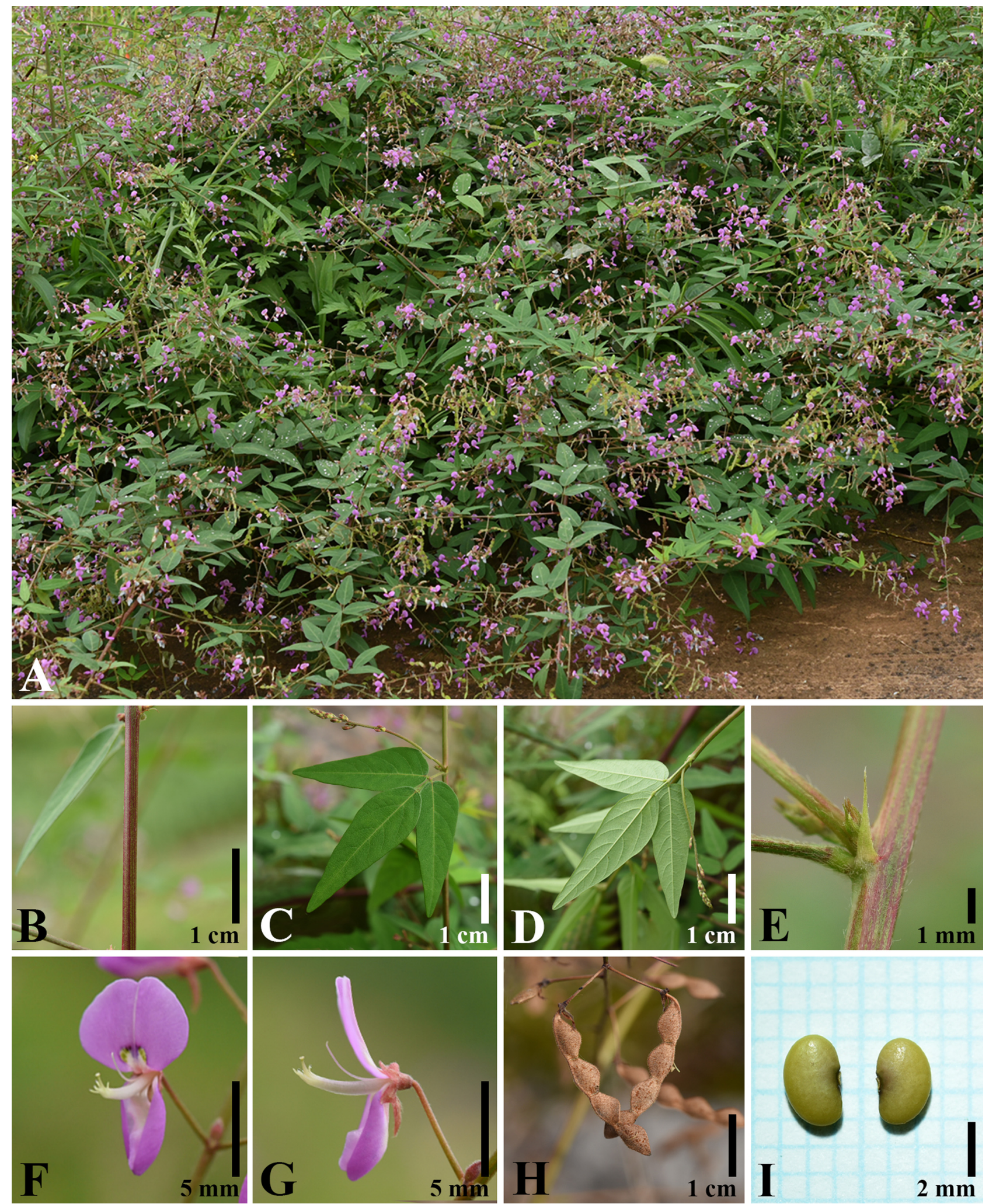

Fig. 1. Photographs of Dsemodium paniculatum (L.) DC. A. Habit. B. Stem. C. Leaf (adaxial surface). D. Leaf (abaxial surface). E. Stipule. F. Flower (frontal view). G. Flower (lateral view). H. Fruit. I. Seed. 


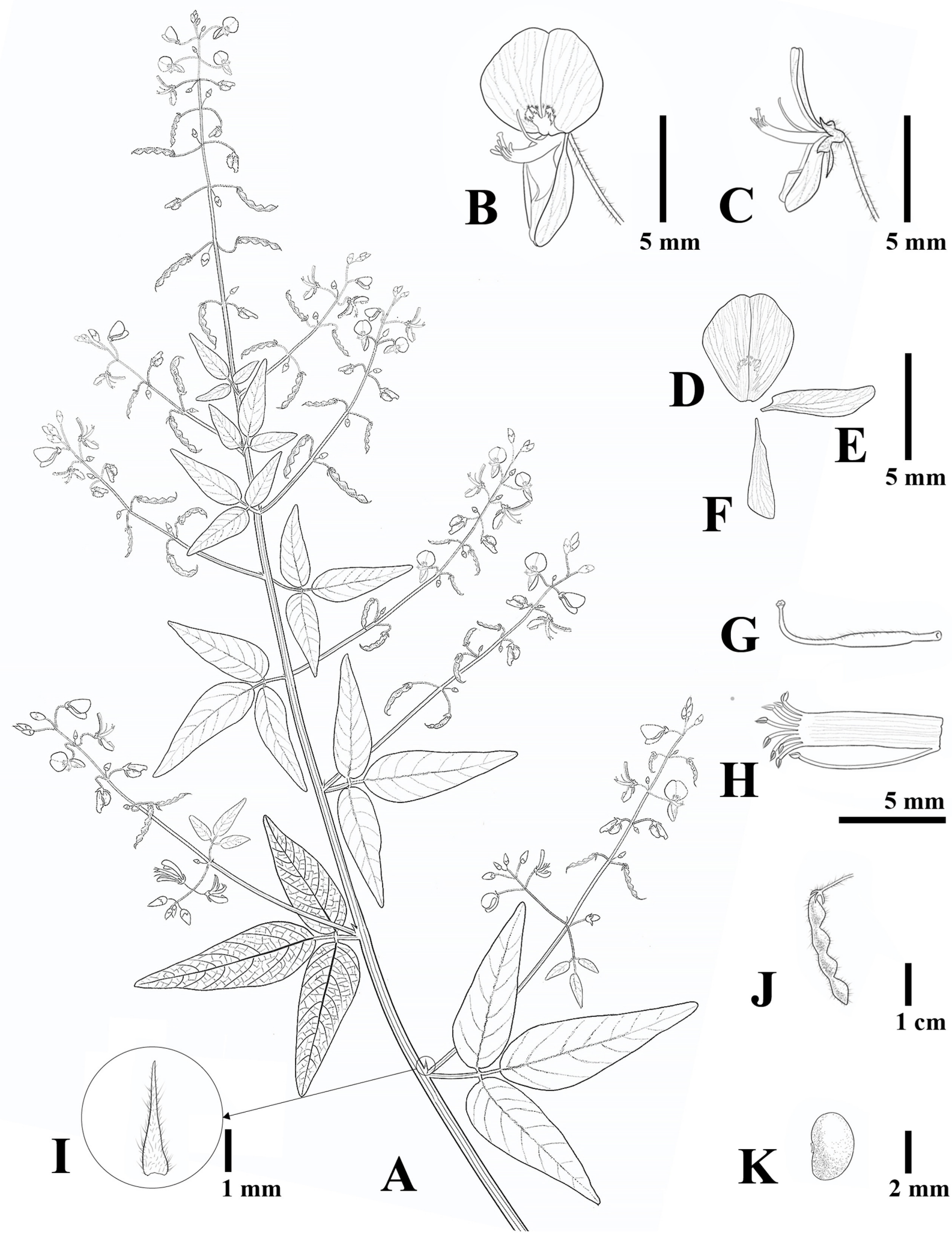

Fig. 2. Illustrations of Dsemodium paniculatum (L.) DC. A. Habit. B. Flower (frontal view). C. Flower (lateral view). D. Standard petal. E. Wing petal. F. Keel petal. G. Pistil. H. Stamens (diadelphous). I. Stipule. J. Fruit. K. Seed. 


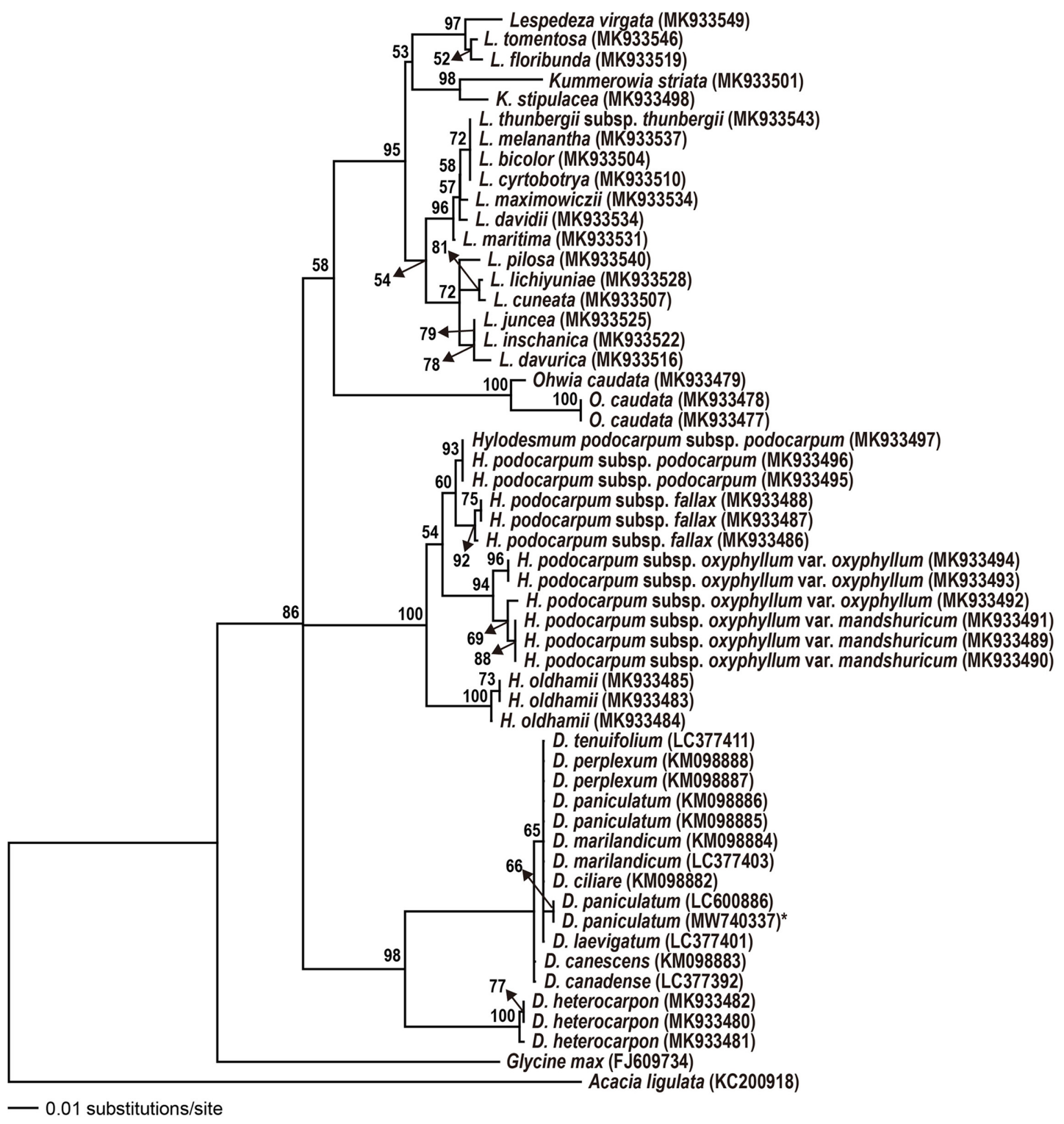

Fig. 3. The Neighbor-Joining phylogenetic tree of tribe Desmodieae based on internal transcribed spacer. Asterisk indicates newly sequenced individuals. GenBank accession number is shown behind scientific name. The number from node indicate bootstrap value ( $>50 \%)$.

Consequently, we provide a description of $D$. paniculatum and an identification key of this species and members of related genera in Korea. Regarding the Korean name of this species, we have referenced the National Species list of Korea (National Institute of Biological Resources, 2019).

\section{Taxonomic Treatment}

Desmodium paniculatum (L.) DC., Prodr. 2: 329, 1825 .TYPE: USA. Virginia, Clayton 184 (lectotype, BM, photo!) (Figs. 1, 2).

Hedysarum paniculatum L. Sp. Pl. 2: 749, 1753; Meibomia paniculata (L.) Kuntze, Revis. Gen. Pl. 1: 198, 1891.
H. glabellum Michx., Fl. Bor. Am. 2: 73, 1803; Desmodium glabellum (Michx.) DC., Prodr. 2: 329, 1825; M. glabella (Michx.) Kuntze, Revis. Gen. Pl. 1: 198, 1891.

D. dillenii Darl., Fl. Cestr. ed. 2: 414-415, 1837; D. paniculatum var. dillenii (Darl.) Isely, Am. Midl. Nat. 49: 927, 1953.

D. perplexum B. G. Schub., Rhodora 52: 154, 1950.

Korean name: Mi-guk-jan-di-gal-go-ri (미국잔디갈고리).

Perennial herb, $50-150 \mathrm{~cm}$ in height. Stem erect or ascending, often branched, terete, striated, pubescent with short hairs and long appressed hairs; stipule narrowly triangular, apex 
acuminate, semipersistent, $2-5 \mathrm{~mm}$ long. Leaves trifoliate, petiolate, 7-11 cm long at middle; leaflets lanceolate, $4-6 \mathrm{~cm}$ $\times 1.5-2.5 \mathrm{~cm}$ wide, apex acute and spined-tip, both surfaces pubescent with short and long appressed hairs. Inflorescence raceme, terminal or axil. Flowers chasmogamous, pink or reddish purple, 6-7 $\mathrm{mm}$ long; pedicels densely pubescent with slightly hooked and straight hair. Calyx campanulate, green to brown, ca. $2 \mathrm{~mm}$ long, 4-lobed, abaxial surface densely pubescent with short hairs and long appressed hairs; lobes longest at lower lobe, slightly clefted at upper lobe. Standard petals obovate, pink or reddish purple with green dotted inside, apex emarginate, base not clawed; wing petals narrowly obovate, apex curved, base auriculate and shortly clawed; keel petal narrowly obovate, paler than standard and wing, base shortly clawed. Stamens diadelphous $(9+1)$, one free stamen diverged basally, exposed at maturing. Pistil narrowly oblong, sparsely curved hair from base to middle. Fruit legume, narrowly oblong, densely curved hair outside, ca. $3 \times 0.4 \mathrm{~cm}$, basal suture incised to upper, isthmus about $1 / 3$ as broad as segment. Seed reniform, glabrous, ca. $4 \times 2 \mathrm{~mm}$.

Flowering: August to October.

Fruiting: October to November.

Distribution and habitat: Desmodium paniculatum is native in North America, whereas this species is non-native in Korea and Japan. This species occurs in open, sunny places at 10-100 $\mathrm{m}$ a.s.l. on river and roadside. The population was composed of 30 individuals within $10 \times 10 \mathrm{~m}^{2}$ in size. It grows together with herbaceous plants such as Equisetum arvense L., Capsella bursa-pastoris (L.) Medik., Draba nemorosa L., Chamaecrista nomane (Siebold) H. Ohashi, Vigna minima (Roxb.) Ohwi \& H. Ohashi, Oenothera biennis L., Acalypha australis L., Euphorbia hypericifolia L., Metaplexis japonica (Thunb.) Makino, Mosla punctulata (J. F. Gmel.) Nakai, Artemisia indica Willd., Aster pilosus Willd., Bidens biternata (Lour.) Merr. \& Sherff, Lactuca indica L., Cyperus microiria Steud., Arthraxon hispidus (Thunb.) Makino, Digitaria ciliaris (Retz.) Koeler, Miscanthus sacchariflorus (Maxim.) Hack., Phragmites japonica Steud., Setaria faberi R. A. W. Herrm., S. pumila (Poir.) Roem. \& Schult., and S. viridis (L.) P. Beauv. Specimens examined: KOREA. Gyeonggi-do: Geumgokri, Dongtan-myeon, Hwaseong-si, 30 Sep 2010, B.-H. Choi and W.-B. Cho 99502 (IUI), 99503 (IUI), 99504 (IUI), 99505 (IUI); Yeongcheon-dong, Hwaseong-si, 15 Oct 2019, J.-H. Kim KIMJH19233 (3 sheet KB); same locality, 17 Sep 2020, J.-H. Kim KIMJH20117 (KB), KIMJH20118 (KB), KIMJH20119 (KB), KIMJH20120 (KB), KIMJH20121 (2 sheet (KB)), KIMJH20122 (3 sheet (KB)); same locality, 3 Nov 2020, J.H. Kim KIMJH20123 (KB), KIMJH20124 (3 sheet (KB)).
Chungcheongnam-do: Mannyeon-dong, Seo-gu, Daejeon-si, 19 Sep 2019, G.-H. Nam KIMJH19228 (KB).

JAPAN. Chiba: Teganomori, Kashiwa, 25 Sep 2010, I. Tanabe INM-2-063142 (KB). Ibaraki: Toyookamachiiinuma, Joso, 3 Sep 2010, E. Gokita INM-2-063138 (KB); Dochi, Moriya, 4 Sep 2010, Y. Wada INM-2-063140 (KB).

\section{Key to $D$. paniculatum and related taxa in Korea}

1. Petioles winged; flower pale yellow or greenish white *. Ohwia 된장풀속

1. Petioles not winged; flower purple or reddish purple.

2. Loment distinctly stipitate, lower suture deeply incised between segments, isthmus less than $1 / 5$ as broad as legume …………………... Hylodesmum 갈고리속

2. Loment sessile or subsessile, lower suture not deeply incised between segments, isthmus more than $1 / 3$ as broad as legume ……… Desmodium 잔디갈고리속 3. Subshrub; stem prostrate; leaflet elliptic or obovate; loment sessile …… D. heterocarpon 잔디갈고리

3. Perennial herb; stem erect or ascending; leaflet narrowly ovate or lanceolate; loment subsessile …

D. paniculatum 미국잔디갈고리

ORCID: Dong-Pil JIN https://orcid.org/0000-0002-3617952X; Jung-Hyun KIM https://orcid.org/0000-0003-26995635; Sunhee SIM https://orcid.org/0000-0001-9788-7653; Hwa-Jung SUH https://orcid.org/0000-0003-2528-425X; JinSeok KIM https://orcid.org/0000-0002-4474-1244

\section{Acknowledgments}

This work was supported by a grant from the National Institute of Biological Resources (NIBR), funded by the Ministry of Environment (MOE) of the Republic of Korea (NIBR202002106, NIBR202102103).

\section{Conflict of Interest}

The authors declare that there are no conflicts of interest.

\section{Literature Cited}

Choi, B.-H. 2007. Desmodium Desv. In The Genera of Vascular Plants of Korea. Flora of Korea Editorial Committee (ed.), Academy Publishing Co., Seoul. Pp. 611-612.

GBIF Secretariat. 2019. Desmodium paniculatum DC. Retrieved 
Mar. 10, 2021, available from https://www.gbif.org/species/ 2967543.

Isely, D. 1983. The Desmodium paniculatum (L.) DC. (Fabaceae) complex revised. SIDA, Contributions to Botany 10: 142-158.

Isely, D. 1998. Native and Naturalized Leguminosae (Fabaceae) of the United States Exclusive of Alaska and Hawaii. Monte L. Bean Life Science Museum, Brigham Young University, Provo, UT, 1007 pp.

Jabbour, F., M. Gaudeul, J. Lambourdière, G. Ramstein, A. Hassanin, J.-N. Labat and C. Sarthou. 2018. Phylogeny, biogeography and character evolution in the tribe Desmodieae (Fabaceae: Papilionoideae), with special emphasis on the New Caledonian endemic genera. Molecular Phylogenetics and Evolution 118: 108-121.

Jin, D.-P., J.-W. Park, J.-S. Park and B.-H. Choi. 2019. DNA barcode and phylogenetic study of the tribe Desmodieae (Fabaceae) in Korea. Korean Journal of Plant Taxonomy 49: 224 239. (in Korean)

Kajita, T., H. Ohashi, T. Nemoto, C. D. Bailey and J. J. Doyle. 1996. Polyphyly of the legume tribe Desmodieae: Evidence from the chloroplast genome. American Journal of Botany 83: $165-166$.

Katoh, K. and D. M. Standley. 2013. MAFFT multiple sequence alignment software version 7: Improvements in performance and usability. Molecular Biology and Evolution 30: 772-780.

Kimura, M. 1980. A simple method for estimating evolutionary rates of base substitutions through comparative studies of nucleotide sequences. Journal of Molecular Evolution 16: 111-120.

Lee, J.-Y., M. J. Kim, C.-K. Oh and B.-H. Choi. 2012. First record of Hylodesmum laxum (Fabaceae) from Korea. Korean Journal of Plant Taxonomy 42: 207-210.

Lee, T. B. 1980. Illustrated Flora of Korea. Hyangmunsa, Seoul, 990 pp. (in Korean)

Li, J., X. Lin, G. Tang, R. Li, D. Wang and S. Ji. 2019. Pharmacognostical study of Desmodium caudatum. Anais da Academia Brasileira de Ciências 91: e20180637.

Mito, T. and T. Uesugi. 2004. Invasive alien species in Japan: The status quo and the new regulation for prevention of their adverse effects. Global Environmental Research 8: 171-191.

National Institute of Biological Resources. 2019. National Species List of Korea. I. Plants, Fungi, Algae, Prokaryotes. Designzip, Seoul, 113 pp. (in Korean)

Ohashi, H. 1999. The genera, tribes and subfamilies of Japanese Leguminosae. The Science Reports of the Tohoku University, 4th Series Biology 40: 187-268.

Ohashi, H. 2005. Desmodieae. In Legumes of the World. Lewis, G., B. Schrire, B. Mackinder and M. Lock (eds.), Royal Botanic Gardens, Kew. Pp. 432-445.

Ohashi, H. 2013. New combinations in North American Desmodium (Leguminosae: tribe Desmodieae). Journal of Japanese Botany 88: 166-175.

Ohashi, H. and R. R. Mill. 2000. Hylodesmum, a new name for Podocarpium (Leguminosae). Edinburgh Journal of Botany 57: 171-188.

Ohashi, H. and K. Ohashi. 2018. Grona, a genus separated from Desmodium (Leguminosae tribe Desmodieae). Journal of Japanese Botany 93: 104-120.

Ohashi, H., R. H. Polhill and B. G. Schubert. 1981. Desmodieae. In Advances in Legume Systematics. Part 1. Polhill, R. M. and P. H. Raven (eds.), Royal Botanic Gardens, Kew. Pp. 292300.

Ohashi, K., H. Ohashi, T. Nemoto, T. Ikeda, H. Izumi, H. Kobayashi, H. Muragaki, K. Nata, N. Sato and M. Suzuki. 2018. Phylogenetic analyses for a new classification of the Desmodium group of Leguminosae tribe Desmodieae. Journal of Japanese Botany 93: 165-189.

Shimizu, T. 2003. Desmodium Desv. In Naturalized Plants of Japan. Shimizu, T. (ed.), Heibonsha Ltd., Tokyo. Pp. 106-107. (in Japanese)

White, T. J., T. Bruns, S. Lee and J. Taylor. 1990. Amplification and direct sequencing of fungal ribosomal RNA genes for phylogenetics. In PCR Protocols: A Guide to Methods and Applications. Innis, M. A., D. H. Gelfand, J. J. Sninsky and T. J. White (eds.), Academic Press, Inc., San Diego, CA. Pp. 315-322. 


\title{
형태와 DNA 바코드에 근거한 한국 미기록 외래식물의 보고, 미국잔디갈고리(공과)
}

\author{
진동필, 김중현, 심선희, 서화정', 김진석 ${ }^{2 *}$ \\ 국립생물자원관 식물자원과 \\ ${ }^{1}$ 대전대학교 생명과학과 \\ 2현소속: 금수강산
}

적 요: 북아메리카 원산이며, 일본에서는 외래식물로 알려진 미국잔디갈고리(Desmodium paniculatum)가 국 내의 화성시와 대전시에서 발견되었다. 본종은 다년생 초본이며, 협과는 4-5개의 소절과로 연결되고, 소절과 사이의 배축면이 완만하게 좁아지는 점에서 국내의 근연분류군들과 구분된다. 미국잔디갈고리는 강변과 도 로변에서 자라고 있어, 하천정비나 도로 공사를 통해 유입된 것으로 추측된다. Internal transcribed spacer 계 통수상에서 한국산 미국잔디갈고리는 일본산 개체와 단계통을 형성하였다. 본 연구는 미국잔디갈고리의 형 태적 특징에 대한 기재와 사진, 도해, 분포 위치에 대해 보고하였다.

주요어: 외래식물, 미국잔디갈고리, 콩과, 미기록, 자원식물 